\title{
Huwelik en huweliksrolle in Afrikaanse kultuur- en kerklike konteks
}

\begin{tabular}{|c|c|}
\hline \multicolumn{2}{|c|}{$\begin{array}{l}\text { Authors: } \\
\text { Annelie Botha }{ }^{1} \\
\text { Yolanda Dreyer }^{1}\end{array}$} \\
\hline \multicolumn{2}{|c|}{$\begin{array}{l}\text { Affiliations: } \\
{ }^{1} \text { Department of Practical } \\
\text { Theology, University of } \\
\text { Pretoria, South Africa }\end{array}$} \\
\hline \multicolumn{2}{|c|}{$\begin{array}{l}\text { Note: } \\
\text { This article represents a } \\
\text { reworked version of aspects } \\
\text { from the PhD dissertation } \\
\text { (University of Pretoria), } \\
\text { entitled "n Transformatiewe } \\
\text { pastoraat vir die huwelik en } \\
\text { kerk in krisis', with Prof. Dr } \\
\text { Yolanda Dreyer as supervisor. }\end{array}$} \\
\hline \multicolumn{2}{|c|}{$\begin{array}{l}\text { Correspondence to: } \\
\text { Annelie Botha }\end{array}$} \\
\hline \multicolumn{2}{|c|}{$\begin{array}{l}\text { Email: } \\
\text { abothaster@gmail.com }\end{array}$} \\
\hline \multicolumn{2}{|c|}{$\begin{array}{l}\text { Postal address: } \\
\text { Private Bag X20, Hatfield } \\
\text { 0028, South Africa }\end{array}$} \\
\hline \multicolumn{2}{|c|}{$\begin{array}{l}\text { Dates: } \\
\text { Received: } 25 \text { Mar. } 2013 \\
\text { Accepted: } 26 \text { May } 2013 \\
\text { Published: } 24 \text { July } 2013\end{array}$} \\
\hline \multicolumn{2}{|c|}{$\begin{array}{l}\text { How to cite this article: } \\
\text { Botha, A. \& Dreyer, Y., 2013, } \\
\text { 'Huwelik en huweliksrolle } \\
\text { in Afrikaanse kultuur- en } \\
\text { kerklike konteks', HTS } \\
\text { Teologiese Studies/ } \\
\text { Theological Studies 69(1), } \\
\text { Art. \#1965, } 9 \text { pages. http:// } \\
\text { dx.doi.org/10.4102/hts. } \\
\text { v69i1.1965 }\end{array}$} \\
\hline \multicolumn{2}{|c|}{$\begin{array}{l}\text { Copyright: } \\
\text { C 2013. The Authors. } \\
\text { Licensee: AOSIS } \\
\text { OpenJournals. This wor } \\
\text { is licensed under the } \\
\text { Creative Commons } \\
\text { Attribution License. }\end{array}$} \\
\hline \multicolumn{2}{|l|}{ Read online: } \\
\hline 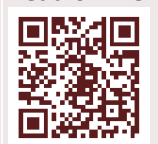 & $\begin{array}{l}\text { Scan this QR } \\
\text { code with your } \\
\text { smart phone or } \\
\text { mobile device } \\
\text { to read online. }\end{array}$ \\
\hline
\end{tabular}

Marriage and marital roles in the Afrikaans cultural and religious context. The article investigates women's socialization in terms of their position in society and the church, and their roles in the marriage relationship. A brief historical overview is given of how the understanding of marriage has developed, with specific emphasis on marriage and marital roles in Afrikaans cultural and religious contexts. The authors examine the ecclesiastical magazines Die Hervormer and Die Jaarboek van die Nederduitsch Hervormde Sustersvereniging (Yearbook of the Netherdutch Reformed Women's Association). The article shows that the message communicated to women who are members of the Netherdutch Reformed Church with regard to marital roles is that they must be submissive. Centuries of conditioning has created submissiveness and inferiority in these women and this has affected them negatively not to be equal to men in society and marriage relationships.

\section{Vraagstelling}

As teoloë en predikante in die Nederduitsch Hervormde Kerk van Afrika (NHKA), wil ons die fokus in hierdie artikel laat val op die boodskap wat die NHKA oor en aan vroue deurgee rakende hulle plek in die samelewing, huwelik en die kerk. Ons ondersoek spesifiek die boodskap soos dit deurkom in kerklike tydskrifte soos die Hervormer en Die Jaarboek van die Nederduitsch Hervormde Sustersvereniging (NHSV). Ons toon aan dat die boodskap wat so oorgedra is aan vroue binne die NHKA bepalend was en steeds is vir hoe vroue hulle rol in die samelewing, kerk en huwelik sien.

Volgens Barnard-Weiss (1999:4) word die NHKA binne die kader van die Afrikaanse susterskerke as die mees behoudende kerk gesien. Barnard-Weiss (1999) beskryf die ontwikkeling van die vroue se kerklike rol in die NHKA soos volg:

Die ontwikkeling van die vroue se kerklike rol in die Hervormde Kerk gedurende die twintigste eeu val in vier redelik duidelike fases uiteen. Van die begin van die eeu tot ongeveer 1920 was dit hoofsaaklik individuele vroue wat in die kerk uitgestyg het. Daarna het 'n tydperk van twintig jaar gevolg wat as aanloop tot die stigting van die Nederduitsch Hervormde Sustersvereniging (NHSV) beskou kan word en waartydens predikantsvroue toenemend ' $n$ rol in die organisasie van vroulike lidmate speel. ... Na die stigting van die NHSV in 1940 het hierdie liggaam die vrou in die Hervormde Kerk verteenwoordig. Dekades lank was die vrou in die kerk aktief as getroue en onvermoeide werkster - nie spesifiek om medegelowiges geestelike te versorg nie, maar veral om geld in te samel om die werk van die kerk moontlik te maak. Haar rol was beperk tot en in lyn met dié aktiwiteite wat gedurende die Victoriaanse era as aanvaarbaar vir die vrou in die samelewing en kerk gegeld het, naamlik barmhartigheid en die beoefening van naaldwerk, kuns en musiek. (bl. 9)

Na debatvoering wat 30 jaar lank geduur het, is vroue in die NHKA in 1957 toegelaat om in gemeentevergaderings te stem (NHKA 1957:23). In 1970 het die Algemene Kerkvergadering beslis dat daar geen Skriftuurlike gronde bestaan om vroue uit die kerklike amp van diaken te hou nie en die besluit het daartoe gelei dat daar in 1973 besluit is om vroue toe te laat in die diakensamp (NHKA 1970:82-83; vgl. Barnard-Weiss 1999:10). Die inskrywing van Yolanda Dreyer in 1975, as eerste vrouestudent wat die BA-kursus aan die Teologiese Fakulteit van die NHKA wou volg met die oog om vir die BD-graad (in teologie) te kwalifiseer, het die NHKA voor die uitdaging gestel om rekenskap te gee van wat die kerk se standpunt oor die vrou op die kansel is. 'n Nuwe era vir die vrou in die NHKA het aangebreek toe daar tydens die Algemene Kerkvergadering van 1979 en 1983 onderskeidelik besluit is dat vroue predikante en ouderlinge mag word (NHKA 1983:55-56).

Die NHKA se verwagting van wat vroue se optrede in die kerk behoort te wees, blyk uit kerklike publikasies en ook die argumente wat gevoer is in die besluite oor die plek en rol van vroue in die kerk. Die kerklike publikasies wat ter sprake is, is die HTS Teologiese Studies/Theological Studies die akademiese tydskrif van die kerk, Die Hervormer - die 'koerant' van die kerk, Die Christelike Vrou - 'n tydskrif vir vroue, die NHSV Jaarboek asook Die Almanak. Milde Barnard-Weiss (1999) vermeld in haar geskiedenisstudie, getitel, 'Die vrou in die Nederduitsch Hervormde Kerk van 
Afrika: Haar beeld en kerklike rol, 1940-1983', dat besinning oor die vrou se posisie in akademies-teologiese verband in daardie tydperk grootliks afwesig was in die HTS Teologiese Studies/Theological Studies Ten opsigte van Die Hervormer word gestel dat daar gedurende die eerste drie dekades van die twintigste eeu feitlik geen beriggewing oor vroue was nie. Daar is wel briewe van vroue in Die Hervormer geplaas en soms doodsberigte van predikantsvroue.

Na die stigting van die NHSV in 1940 is daar een bladsy per uitgawe van Die Hervormer afgestaan vir die aktiwiteit van die vereniging (Ras 1943:38). Drie jaar na die stigting van die NHSV is begin met 'n eie blad, Die Christelike Vrou. Die redaksie van die blad is saamgestel uit vroue van predikante en professore (Barnard-Weiss 1999:29). Titels van rubrieke wat geskryf is was onder meer: 'Huis en haard', 'Ons en ons kinders', 'Die vuur van die huisaltare', 'Gedachten na boven', 'Vir ons kinders' en 'Om die huis tafel' (NHSV Jaarboek 1967-1968:107, 109). Barnard-Weiss (1999) beskryf die NHSV Jaarboek soos volg:

In teenstelling met Die Christelike Vrou, wat die NHSV se eie mondstuk was en meer na binne gerig was, was die Jaarboek van die NHSV (of NHSV Jaarboek) die koppelvlak tussen die vroue in die vereniging, die manlik gedomineerde kerk en die samelewing. Die kerk het deur die Jaarboek met die vrou gepraat op 'n ander vlak as die suiwer teologiese. (bl. 33)

Volgens Walker (1990:25) was die posisie van vroue in die Suid-Afrikaanse samelewing in die eerste helfte van die twintigste eeu gekenmerk deur 'n bepaalde verstaan van geslagsrolle wat gebaseer was op 'n Blanke, Westerse, Christelike model. Dit het gegaan oor huislikheid, moederskap, kinderopvoeding en onderdanigheid aan die gesag van die man. Blanke vroue wat tot die middel- en hoër inkomstegroepe behoort het, moes verkieslik nie buitenshuis werk vir 'n inkomste nie. Na die Tweede Wêreldoorlog was die tradisionele konsep van die 'huisvrou' nog stewig in Suid-Afrika gevestig. Dit is ondersteun deur die SuidAfrikaanse regstelsel wat bepaalde beperkings op vroue, en veral getroude vroue geplaas het (Barnard-Weiss 1999:49). Getroude vroue wat binne gemeenskap van goedere getroud is, het byvoorbeeld die status van 'n minderjarige kind gehad.

Volgens Brink (1990:273-292) word die ideaal wat aan Blanke Afrikanervroue gestel is, in die negentiende en twintigste eeu ook aangetref in Brittanje, Amerika, Kanada en Frankryk. In die Afrikaanse samelewing is die beeld van die voedende moeder uitgebrei om ook geestelike voeding van die volk te impliseer met die doel om Afrikanernasionalisme te ondersteun. So ontstaan die begrip volksmoeder:

The volksmoeder ideal promoted a dependent position for women, as participants in the lives of their husbands and children rather than active in their own lives. Only within this circumscribed role could women achieve social recognition. (Brink 1990:291)

Hoewel daar vroue in die Suid-Afrikaanse samelewing was, wat hulle teen sekere fasette van hierdie beeld en die geslagsrol onderdrukking uitgespreek het, was vroue oor die algemeen konserwatief en gekant teen enige verandering ten opsigte van hulle posisie van onderdanigheid. Redes wat hiervoor aangegee word, is die gevare vir vroue wat in opstand sou kom en die samelewing se beloning van konformiteit (Walker 1990:30). Sodra ' $n$ vrou die voorgeskrewe rol begin bevraagteken, verloor daardie samelewing die mag oor so 'n vrou en die vrou verloor die voorregte wat aan die voorgeskrewe rol gekoppel is (vgl. Brink 1990:273). Ten spyte van ingrypende sosiale veranderinge gedurende die twintigste eeu, het die onderdanigheid van vroue aan mans bly voortbestaan. Dit is ' $n$ aanduiding van hoe diepgewortel persepsies ten opsigte van geslag is (Walker 1990:31; vlg. Barnard-Weiss 1999:53).

Die toekenning van politieke stemreg aan vroue in die dertigerjare van die twintigste eeu kan die indruk skep dat die regte van vroue 'n aktuele saak was, maar volgens Barnard-Weiss (1999:53) is die teendeel egter waar. Volgens haar het die stemregtoegewing nie werklik oor die regte van vroue gegaan nie, maar om die versterking van Blanke teenoor Swart stemkrag (vgl. Walker 1990:24).

Met die Tweede Wêreldoorlog het die posisie van vroue in die samelewing verander. Vroue moes byvoorbeeld in die industrie en fabrieke die plek gaan inneem van mans wat in die oorlog gaan veg het. Die verklaring van menseregte wat deur die Verenigde Nasies uitgevaardig is, het ook diskriminasie op grond van geslag veroordeel. In die SuidAfrikaanse reg het daar ook 'n verandering ingetree in 1945. Tot toe is vroue se regsbevoegdheid ingekort sodra hulle trou; die man het namens die vrou na buite opgetree en meestal ook beheer oor haar eiendom verkry; hy kon die gesamentlike woonplek kies en hy moes toestemming gee as sy vrou buite die huis wou werk (Pont 1945:11-14). Groter wetlike vryheid het aan vroue die geleentheid gebied om stadig maar seker in die gemeenskap na vore te tree. Daar was egter ' $n$ mate van ambivalensie in die samelewing ten opsigte van die emansipasie van vroue. In 1959 het Johanna M. Raath (1961-1962:20), voorsitter van die Suid-Afrikaanse Vrouefederasie by 'n NHSV-kongres vroue se toenemende toetrede tot die arbeidsmark as 'n vraagstuk bestempel. Sy het vroue wat buitenshuis werk se motiewe bevraagteken en gehoorsaamheid aan die wil van God, naamlik vroue se roeping tot moederskap, as die Christenvrou se enigste moontlike lewensuitkyk gepropageer (Raath 1959-1960:40; vgl. Barnard-Weiss 1999:56). Die toetrede van vroue tot die arbeidsmark is deur Raath (1959-1960:46) as 'n bedreiging vir die huisgesin gesien. Vroue wat ekonomies aktief is, is voorgestel as "n vermande vrou' en die emansipasie van vroue is as ' $n$ tweede sondeval bestempel omdat dit die vrou se hunkering na 'n ander ereplek verteenwoordig as wat deur God aan haar toegewys is (Raath 1959-1960:51).

Dit is hierdie tipe kultuurdruk op vroue wat maak dat vroue in die NHKA die rolle wat aan hulle voorgehou is bly vervul het. Ackermann (1984:75) beskryf die fenomeen soos volg: 'This kind of conditioning makes acceptance of a stunted way of life possible - you become what is expected of you, having no other images to identify with.' Van binne die NHKA is die ruimte wat vroue gegun is, beperk ten spyte daarvan dat meer 
geleenthede vir vroue in die samelewing moontlik geword het. Die kerk se teenstand teen die nuwe wetgewing toon dit duidelik. Die kerk het die wysiging van die huweliksreg waardeur'n getroude vrou gelykwaardig aan haar man geag is voor die wet en sonder sy toestemming buite die huis kon werk, veroordeel (Barnard-Weiss 1999:61). Hierdie wysiging asook die afskaffing van die man se mag oor sy vrou, is gesien as strydig met die NHKA se huweliksbevestigingformulier. Daan Pont (1945:13-14), 'n Hervormde regsgeleerde, stel dit soos volg: 'Ook hier is die wetsontwerp in stryd met ons kerklike Huweliksformulier en daarom weer vir elkeen wat die kerklike opvatting ook huldig onaanneemlik.'

Tydens die NHSV-kongres wat op 06 Maart 1945 gehou is waar Pont hierdie uitsprake gemaak het, het die kongres besluit dat die voorgestelde wysiging van die huwelikswet 'strydig is met die grondliggende beginsels van die Christelike beskawing in Suid-Afrika' (Pauw 1958-1959:38).

Die implikasie van hierdie besluit is dat hierdie vroue aanvaar het dat mans op feitlik alle terreine behalwe in die huishouding beheer oor vroue mag uitoefen (BarnardWeiss 1999:62). Hoewel die veranderende rol van die vrou toenemend in die kerklike publikasies aandag geniet, is die tradisionele siening steeds te sien in 'n 1981-publikasie:

Die vrou is hier vir een doel en dit is om kinders te baar en Christelik groot te maak; nie om te werk nie ... 'n Vrou se verstand ... is ingestel op kinders en om vroulik te wees. God het ons toekoms en plig bepaal. Ons moet ons nie laat mislei nie. (Engelbrecht 1981:14)

Hoewel hierdie maar die uitspraak van een manlike lidmaat van die kerk was, is dit 'n weerklank van vorige uitsprake van predikante van die kerk, soos die van ds. E.S. Mulder (1949:11) wat dit soos volg stel: 'Die skoonheid van die vrou lê juis daarin dat sy vrou is, in haar ingetoë houding, in goeie werke, in moederskap.' Die gelykheid of ongelykheid van man en vrou het vir die NHKA op twee terreine gelê, naamlik die huis en die kerk. Bybelse voorskrifte ten opsigte van die verhouding tussen man en vrou in die huwelik het 'n bepalende invloed op die siening van gelykheid tussen man en vrou gehad:

Verskeie denkpatrone in die gereformeerde teologiese tradisie, soos die positivisme, die fundamentalisme en die biblisisme, het daartoe aanleiding gegee dat die Bybel baie jare lank gebruik is om te motiveer waarom die vrou in geen regerende amp in die kerk mag staan nie. Die verskuiwing van die sekulêre paradigma oor die plek van die vrou het dus vir die kerk in die algemeen 'n krisis geskep, omdat dit die aanvaarde Skrifbeskouing ten opsigte van die vrou in gedrang gebring het. (Barnard-Weiss 1999:67)

Uit bogenoemde is dit duidelik dat die argument wat gebruik word dat wetgewing wat vroue se plek en rol in die huwelik verander, strydig is met die kerk se huweliksbevestigingsformulier en strydig is met die Christelike beginsels wat uit'n bepaalde Skrifbeskouing kom, 'n Skrifbeskouing waar kultuurtradisies die interpretasie van Bybel gedeeltes ten opsigte van die huwelik stuur (vgl. Dreyer 2008:486-487).

\section{Afrikaanse kultuur- en kerklike konteks}

Die erfenis van Afrikaanssprekende gelowiges in SuidAfrika in terme van huweliksrolle is diep gewortel. Christina Landman (1994), beskryf in haar boek: The piety of Afrikaans women: Diaries of guilt, die historiese erfenis wat Afrikaanssprekende vroue se siening oor hulleself en hulle rol in die samelewing en huwelik bepaal het. Landman (1994:vii) beskryf die vroue as 'voormoeders' hulle wat in die agtiende-eeuse Kaapkolonie op grensplase gewoon het, wat deel gevorm het van die Groot Trek van Afrikaanssprekendes uit die Britse Kaap, en wat in die Boereoorlog die Britse konsentrasie kampe oorleef of nie oorleef het nie. Hierdie vroue het geen teologiese onderrig gehad nie. Die samelewing het vroue beskou as 'Eva' en hulle verantwoordelik gehou vir die swaarkry van die samelewing (Landman 1994:vii). Hulle het geglo dat hulle hierdie skuld moet dra en dat hulle hulle lot kan verander deur God tevrede te stel.

Die beeld van God wat na vore kom uit die dagboeke van Afrikaanse vroue wat geskryf is tussen 1749 en 1964 blyk dat hulle geglo het in 'n veeleisende manlike God, wat behaag en gelukkig gehou moes word en wat dié bemagtig wat dit regkry om God tevrede te stel (Landman 1994:64). Hulle het met gelatenheid hulle onderdanigheid aan mans aanvaar om so die guns van die manlike dominante kultuur (en van God) te wen. In hulle kompetisie vir die guns van hierdie manlike dominante kultuur, was en is hulle steeds dislojaal teenoor mekaar. Die beperkings wat hulle subkultuur aan hulle stel, lei daartoe dat hulle agterdogtig is ten opsigte van ander kulture, in besonder die Britse en die Swart kulture. Hierdie vroomheid van selfhaat en onderdanigheid het dit moontlik gemaak vir die mans van die dominante kultuur om die vroomheid van die vroue te gebruik om hulle te verhoed om deel te neem aan die openbare lewe, ook om hulle onwetend te betrek by die manlike nasionalistiese stryd.

Wat bygedra het tot die vorming van Afrikaanse vroue se piëteit, se negatiewe selfbeeld, hulle oordrewe persoonlike skuldgevoel en sondebesef, asook hulle beeld van God, vanaf die sewentiende tot die twintigste eeu, is onder andere die boeke wat deur die Afrikaanse vroue gelees is in bogenoemde tydperk (Landman 1994:8-17). Hierdie inligting bekom Landman (1994:11-17) uit die dagboeke van vroue wat na hulle dood gepubliseer is, soos byvoorbeeld die van Catharina Allegonda van Lier (1768-1801), Hester Venter (geb. 1750) en Matilda Smith (1749-1821). Van Lier is beïnvloed deur evangeliese Engelse skrywers soos John Newton, en piëtiste soos De Bres en Duitsch, asook Van Alphen en Van de Kasteele. Venter is beïnvloed deur Nederlandse piëtiste en in besonder deur Bernardus Smijtegelt se boek, Het gekrookte riet. Matilda Smith was een van Van Lier se naby vriendinne en huldig dieselfde gedagtes as Van Lier. Die dagboeke gee blyke van die Afrikaanse vroue se piëteit, hulle oordrewe skuldgevoelens, negatiewe siening van hulleself, en beeld van 'n veeleisende God (Landman 1994:12). Die 
belangrikheid van hierdie vroue se bydraes en invloed op die lewe van Afrikaanse vroue is die feit dat hulle dagboeke na publikasie wyd gelees is, en ook verskeie herdrukke beleef het (Landman 1994:21-22, 38).

In die dagboek van Van Lier (1804), Dagboek, gemeenzame brieven en eenzame overdenkigen, word dit duidelik hoe bewus sy van haar eie sondigheid was, en hoe hierdie bewussyn haar selfbeeld en haar Godsbeeld beïnvloed het. Sy sien haarself in 'n negatiewe lig:

Deur God se genade het ek myself leer ken as iemand wat volledig skuldig is, as ' $n$ doemwaardige sondaar, melaats van kop tot tone, onbekwaam om enige goed te doen, verslaaf aan die Satan ... (Van Lier 1804:3; [my vertaling])

Van Lier (1804:20) sien God as veeleisend, en sy beklemtoon die lyding van Jesus, lyding waarvoor sy as sondaar verantwoordelik was. Die Heilige Gees oortuig haar daarvan dat sy 'n sondaar is. Vir Van Lier (1804:22) is God hoog in die hemel, eerder as teenwoordig en betrokke op die aarde. God is haar Hemelse Vader, wat aan haar kant is. Sy glo in 'n goeie God, hoewel sy God nie eksplisiet as barmhartig beskou nie (Van Lier 1804:30, 36, 48). Sy sien God as Regter wat mense wette gee waarvolgens hulle moet lewe (Van Lier 1804:16, 63). God is die een wat die wette en die weg tot verlossing gee, en Jesus is die een wat die verlossing vir mense ' $n$ werklikheid laat word. John Newton (1725-1807) was een van die outeurs wat die grootste invloed op haar selfverstaan en sondebesef gehad het. Van Lier het die negatiewe opmerkings ten opsigte van die menslike natuur in Newton (1840) se werke buite konteks en verband gehaal en volgens die konteks van haar subkultuur konteks aangewend as die bevestiging van haar negatiewe siening van haarself (Landman 1994:29-30). Die oorheersende godsdienstige ervarings van Van Lier (1804:2-15) is selfhaat, skuld en depressie.

Hester Venter wat in 1750 gedoop en op sestienjarige leeftyd getroud is, het saam met haar man op grensplase in die Swellendam-distrik gewoon. Sy huldig dieselfde gedagtes as Van Lier rakende sonde en skuld. Die boek van Bernardus Smijtegelt (1856), 'n Nederlandse piëtis van die Nadere Reformasie, Het gekrookte riet, het 'n bepalende invloed op haar lewe en geloof gehad (Venter 1852:6), en dit lei daartoe dat sy die piëtisme aanhang. Venter het in gevaarlike omstandighede op die grensplaas geleef. Sy druk haar vrees uit in godsdienstige taal - die vrees om vermoor te word, of dat een van haar familielede sou sterf as gevolg van siekte, asook haar vrees om verlore te gaan (Venter 1852:4-6). Na haar bekering tot Smijtegelt (1856) se piëtisme het sy bevry gevoel van die vrees dat sy haar siek dogter sou verloor. Sy het die verlossing in Christus verstaan as verlossing van vrees vir die dood (vgl. Landman 1994:40). Venter (1852:8-9) het verlossing van sonde verstaan as verlossing van depressie. Verdrietigheid het sy beskou as sonde en vreugde was 'n teken van verlossing. Sy het groot klem geplaas op haar sondigheid. Sy het geglo dat haar sondigheid haar ongeluk veroorsaak en dat God betrokke is in die lewens van mense as gevolg van hulle sonde. Sonde is die plek waar God en mens ontmoet, in die stryd teen die vyand wat sy 'Satan' noem (Venter 1852:9). As sondaar kan sy reken op Jesus se nabyheid, omdat sondaars so belangrik is vir Jesus dat Hy sy lewe vir hulle gegee het. Sy sien Jesus as die geliefde in Hooglied (Venter 1852:15). Jesus se lyding word vir Venter (1852:142) 'n daad van fisiese liefde. Sy identifiseer die fisiese met die spirituele. Sy druk haar verhouding met God/ Jesus uit in terme van 'n liefdesverhouding, hoewel sy die verhouding uitsluitlik as geestelik verstaan. Sy stel dit soos volg: 'door uwen geest gezuiverd, mijn lieve Jezus, mijn beminde God ... Here, in hartsmeltende liefde en dankzegging voor uwe groot genade' (Venter 1852:109). Sy het 'n persoonlike verhouding met God/Jesus en met Satan.

Venter se ervaring van God se teenwoordigheid het die vorm van visioene of oomblikke van geestesvervoering aangeneem: 'Het was mij alzoo ettelijke malen gebeurd dat ik met liefde getrokken werd, dat ik wist in welk eene zoete hemelsgestalte ik was' (Venter 1852:11). 'n Toestand van depressie het dikwels gevolg op hierdie euforiese ervarings. Die oorsprong van hierdie depressie was vir Venter (1852) haar bewustheid van haar sonde:

Maar in zulke zoete gestalten kwamen mij weer mijn zonden voor't gezigt, en schenen zoo groot en zwaar voor den Heer dat ik dacht, nu zal de Heer niet weer naar mij omzien, ja, dat ik mijzelve voor een walglijk zondig monster aanmerkte voor den Heer met mijne zware zondeschuld. (bl. 12)

Met hierdie bewussyn van sonde het ook fisiese pyn gepaard gegaan en sy het hartkloppings ervaar. Haar worsteling met Satan het nie net 'n invloed op haar gees gehad nie maar ook op haar liggaam. Venter (1852:14) stel dit soos volg: 'maar ik was krank naar ziel en lichaam.'

Hierdie selfde selfverstaan en gedagtes van sonde en skuld wat by Hester Venter voorkom word ook gevind in briewe wat Magdalena Jonker (1765-1831) aan vroue familielede skryf. Haar briewe saam met ' $n$ kort biografie is in De Gereformeerde Kerkbode (1850-1851) gepubliseer. Die feit dat haar briewe gepubliseer is deur 'n ene ds. Robertson, wat deel was van die Gereformeerde leierskap in daardie tyd, dui daarop dat hierdie soort piëteit van vroue aanvaarbaar was vir die dominante manlike kultuur (kyk Landman 1994:45). Jonker se gunsteling boek was Smijtegelds Keurstoffe. In hierdie sfeer van piëteit sien sy haarself as 'een hoop vuilnis' (Jonker 1850b:208). Jonker onthou dat dit haar pa was wat by haar 'n vreeslike vrees vir God ingeprent het (Jonker 1850a:121). Sy het tot die gevolgtrekking gekom dat 'n mens swaar kry wanneer 'n mens sigself meer lief het as vir God (Jonker 1851a:170) en as haar kinders vir haar afgode was, omdat sy hulle meer liefgehad het as vir God. Daarom het haar kinders dan ook gesterf (Jonker 1850c:148). Met die afsterwe van haar man het Jesus vir haar sy plek ingeneem. Sy het Jesus beskou as haar bruidegom (Jonker 1851b:184).

Matilda Smith (1749-1821) was 'n tydgenoot van Van Lier en Venter. Matilda Smith is gebore op 17 Augustus 1749 as Machteld Combrink. In 1770 is sy getroud met Johan(n) G.J. Grabe. Hy sterf in 1776 en sy trou weer in 1778 met Johannes C. Smith (Schmidt) wat sterf in 1787. Die eerste 
37 jaar van Smith se lewe word gekenmerk deur dood en verlies. Agt van haar nege kinders en haar twee mans sterf as gevolg van siekte. Hoewel Smith reeds 'n gelowige was word sy deur dominee Helperus Ritzema van Lier 'bekeer'. Hierdie bekering help haar om haar lot te aanvaar met geloofsgehoorsaamheid, nederigheid, onderdanigheid. Op 49-jarige leeftyd skryf sy haar lewensverhaal. Smith (Philip 1824:7-9) verstaan die dood van haar kinders en mans in terme van haar geloof, naamlik dat sonde die oorsaak van beproewinge is en dat verlossing verkry kan word wanneer God in genade vergifnis skenk. Die Bybel was volgens Smith (Philip 1824:9) die riglyn vir haar lewe. Die lees van die Bybel het haar egter bang gemaak. Wanneer sy gelees het van Jesus se lyding het sy gevoel soos 'n veroordeelde misdadiger (Philip 1824:10). Smith (Philip 1824:12) skryf die dood van haar seun Godfried Hermanus Grabe toe aan haar rebelse hart wat nie wou buig in onderdanigheid aan God se wil nie. Volgens Smith (Philip1824:19) sterf haar kinders as gevolg van haar sonde en ongeregtigheid.

Smith (Philip 1824:22) vertel van haar ontmoeting van dominee Helperus Ritzema van Lier, die broer van Catharina Allegonda van Lier, wat 'n predikant in die Nederduitse Gereformeerde Kerk aan die Kaap was. Hy het vir haar die antwoorde gegee op die vrae wat sy gehad het oor die lewe en dood. Dominee Van Lier het haar vertel dat Jesus dag en nag beskikbaar is om te luister na haar probleme en vrese. Van Lier se boodskap het dit vir Smith moontlik gemaak om te glo dat Jesus vir haar persoonlik gely het. Dit het vir haar rustigheid en geborgenheid gebring (Philip 1824:28).

Smith het betrokke geraak by sendingwerk te Roodezand, sowat 100 kilometer van die Kaap af (Philip 1824:57). In daardie tyd het sy steeds die waardes van haar subkultuur onderskryf, naamlik die onderdanigheid van vroue en die oordrewe beklemtoning van sonde. Haar Godsbeeld het egter verander. Sy het God nou begin sien as 'n voorsienige God wat vir haar sorg in tye van siekte en dood. Haar Godsbeeld het verander na een van God as Vader wat haar liefhet en seën soos 'n vader sy kinders liefhet en vir hulle goeie dinge moontlik maak (Philp 1824:58).

Mans se siening oor die piëteit van vroue ten tye van die Groot Trek, word duidelik uit die werke van Willem Postma (1918) en Eric Stockenström (1921). Stockenström het klem geplaas op die volgende karaktertrekke van Boervroue tydens die Groot Trek: vroue was 'dienstig in die maak van kos en die voorbereiding van ammunisie' (Stockenström 1921:71). Vroue was patrioties, ongeletterd en daarom eenvoudig en sedelik. Hulle het mans gered deur God se leiding. Vroue was gewillig om alles op te offer vir hulle vryheid en was vreesloos as gevolg van hulle geloof in God (Stockenström 1921:70, 80-81, 84, 92). 'n Voorbeeld hiervan was Erasmus Smit se vrou, Susanna Smit (Stockenström 1921:99). Sy was die suster van Gert Maritz, een van die leiers van die Groot Trek. Sy is gebore as Susanna Catharina Maritz op die 28 Augustus 1799. Op die ouderdom van 13 jaar het Erasmus Smit haar gevra om met hom te trou en haar ma het die toestemming daartoe gegee. Erasmus Smit was 21 jaar ouer as Susanna. Sy was egter nie ongeletterd, naïef, vreesloos of 'n onkritiese ondersteuner van die manlike konsep van nasionale vryheid, soos wat Stockenström die vroue van die Groot Trek beskryf het nie.

In die jare na 1930 is dagboeke van Susanna Smit in 'n kelder in 'n huis in Utrecht, Natal ontdek (Steenkamp 1939:68; kyk Landman 1994:61). Smit was geletterd en bekend met die sewentiende-eeuse piëtisme. Sy het die werke van onder andere Wilhelmus à Brakel (1635-1711), Theodorus van der Groe (1705-1784) en John Newton (1725-1807), Petrus Broes (1726-1802) geken en sy haal ook aan uit die evangeliese gesange van Hieronymus van Alphen (kyk Roodt-Coetzee 1961:38-9; vgl. Raath 2003:143).

Smit lei 'n sedelike lewe, maar sy fantaseer oor Jesus as haar geliefde, as held wat haar red van haar vyande. Soos Venter en Van Lier, sien sy haarself as bruid van Christus. In haar dagboeke beskryf Susanna Smit (1839-1863 Dagboek 3) haar persoonlike en subjektiewe omgang met Christus soos volg:

O hoe verlang mijn ziel haren vriendelijke Heer Jesus Christus weder in het oog te krijgen ... Slegts eene aanblik van uw liefd dringend oog is genoeg om mijn weder te omgorden met kracht en drang ten goede. Ach zalige aanblik, uwe warmte veranderd de koude hand, des doods tot een koesterende bakermande voor hen die Jesus lief hebbe ...(bl. 16)

Susanna Smit was nie vreesloos nie. Sy het God se oordeel en straf gevrees (kyk Landman 1994:63). Raath (2003) beskryf dit soos volg:

Sy bekommer haar oor haar eie sondige neigings en sieleheil en die van haar seuns. Die drome en gesigte wat na haar toe kom, beskou sy as deur God ingegee om as openbaringe of waarskuwings te dien. (bl. 143)

Susanna Smit sien God as naby, maar ook as bedreigend. Sy sien haarself as kind van God die Vader, 'n kind wat haar vader lief het maar ook vrees. Sy het voortdurend skuldig gevoel oor haar optrede voor God. Die skuld en verwerping wat sy ervaar, kom navore in die volgende gebed:

Vader wat zal ik met mijn zelfs beginnen ik weet geen Raad help mij barmhartig Heer uw grote naam tereer. Ach kom mij tog te stade, vergeef de zware schuld die mij met schrik vervuld bewijs mij uw genade, en dan weder op de knieën. Ach Here ziet toch mijn smarte, pijn en elende aan, en verlost mij van de hoogmoed, eerzucht, werelds gezindheid. (Smit Dagboek [18 Februarie 1843])

Uit die optrede van Susanna Smit tydens die besoek van Henry Cloete'n koloniale amptenaar, aan die Trekkergemeenskap in Pietermaritzburg in Augustus 1843, is dit duidelik dat sy nie maar net ' $n$ onderdanige patriot was wat kos en ammunisie vir die mans gegee het nie. By hierdie geleentheid het sy die woorde waarvoor sy bekend geword het, dat hulle eerder kaalvoet oor die Drakensberg sal terug trek as om onder die Engelse bewind te bly, geuiter (kyk Landman 1994:63; Raath 2003:122-123). Volgens Roodt-Coetzee (1961:29) en Cloete (1992:48) het Smit nie net in haar toespraak negatief gereageer teenoor die Engelse imperialisme nie, maar ook teenoor Afrikaanse mans wat nie by hulle woord gehou het nie. Die 
mans het die vroue stemreg belowe in die nuwe regering. Hulle het nie hulle belofte nagekom nie (vgl. Bird 1888:256259). Ten spyte van haar skerp woorde het Susanna Smit onder die Engelse regering in Pietermaritzburg gebly. Haar man het naamlik besluit om te bly en daarom moes sy ook. In haar dagboeke toon Susanna Smit belangrike insigte ten opsigte van rassisme, seksisme en outoritarisme. Sy het haar uitgespreek vir die politieke regte van vroue en die hiërargie in Christelike gemeenskappe gekritiseer. Volgens Landman (1994:75) is die redes waarom hierdie boodskap wat Smit vir haar kultuur en tyd gehad het, nooit effektief gehoor is nie eerstens omdat sy tot die subkultuur van vroue behoort het en tweedens haar piëteit wat gesentreer was rondom vrees vir God, haar persoonlike en geïndividualiseerde verhouding met die God, en verlammende swak selfbeeld.

Vroue dagboeke wat dateer uit die tyd van die SuidAfrikaanse oorlog van 1899-1902, gee 'n aanduiding van die vroue se selfverstaan, selfbeeld en Godsbeeld. Alie Badenhorst (1866-1908) was 33 jaar oud toe die oorlog uitgebreek het. Haar dagboek is deur Emily Hobhouse in Engels vertaal en in 1923 in London uitgegee onder die titel, Tante Alie of Transvaal: Her diary 1880-1902. Die Afrikaanse uitgawe is in 1939 gepubliseer onder redaksie van die Afrikaanse skryfster MER (1875-1975) met die titel, Tant Alie van Transvaal: Die dagboek van Alie Badenhorst.

Alie Badenhorst, gebore De Wet was 17 jaar oud toe sy onder die invloed van Andrew Murray gekom het. Murray het in 1883 in die Potchefstroom distrik gepreek, en tydens 'n besoek aan haar suster het Badenhorst hom gehoor praat (Badenhorst 1923:41-54). Die God wat Murray verkondig het, was 'n persoonlike God wat persoonlike toewyding gevra het. God is persoonlik betrokke by die individu, soos wat die individu 'n persoonlike verhouding met God het (vgl. Van Zyl 1989:6-12,74). Badenhorst (1923) beskryf haar worsteling met hierdie nuwe konsep van God soos volg:

That night the struggle was in my soul, and still I found no peace. Satan would not let me go. He whispered to me that if I were converted I could have no more pleasures but must put them all aside. Then, too, what would the people at home think of me? I feared they would mock at me. Here then were two spirits that fought within me, Christ and Satan; and what had Satan to offer me? Nothing but Eternal Fire while Christ offered me Eternal Life .... Christ is everything: I am nothing. It was to me as if I saw Heaven open and the Spirit of God light upon me, as in silence I yielded myself to Him. Then great peace filled my heart. (bl. 44-45)

Badenhorst was 'n Christen voordat sy Murray se verstaan van God aanvaar het. Na haar bekering het Badenhorst (1923:55-61) alle ligsinnigheid vermy en glad nie partytjies en huweliksfeeste bygewoon nie. Tydens die oorlog het Badenhorst (1923:97100) God beskou as haar manlike beskermer, as haar helper, ondersteuner en Vader. Wanneer sy slegte tyding ontvang het het sy haar persoonlike God om hulp gevra: 'I will trust in my God. He alone can help us' (Badenhorst 1923:93). Badenhorst (1923:105) was soos haar voormoeders onderdanig en lojaal in haar piëteit, sy het God nie gesien as die oorsaak van die oorlog en swaarkry nie, en sy het haar onderwerp aan God se wil om nie 'n einde te maak aan die oorlog en die swaarkry nie. In Februarie 1900 het Badenhorst (Badenhorst 1923:130) 'n besoek van 'n 'boodskapper van God' ontvang. Die boodskapper het haar voor 'n keuse gestel om oor die lot van haar man Frikkie Badenhorst, te besluit. Sy moes kies tussen dood, verwonding of gevangeneming. Sy het gekies dat hy gevange geneem word. Die nuus dat Generaal Cronje en 1300 van sy manne, wat Badenhorst se man ingesluit het, gevange geneem is deur Britse soldate, het daartoe gelei dat sy haarself gesien het as die oorsaak van haar eie swaarkry (Badenhorst 1923:124133). 'n Preek deur ds. Winter, die plaaslike predikant, wat hierdie terugslag geblameer het op die persoonlike sonde van die mense, het vir Badenhorst (1923:132) 'n verklaring gebied vir die gebeurtenis. Sy het geglo dat sy moes besluit oor die lot van haar man omdat sy so 'n sondige mens was. Op 15 April 1901 is Badenhorst en haar kinders na die konsentrasiekamp te Klerksdorp geneem. Sy het hierdie reis na die konsentrasiekamp as vernederend beleef. Haar verblyf in die konsentrasiekamp het 'n nuwe tema in haar godsdienstige ervaring na vore gebring. Sy het God naamlik ervaar as die een wat straf:

It seemed in truth as if God's hand were too heavy upon us, both man and beast. O God, dost Thou strive with us in Thine anger and chastise us in Thy wrath. Be merciful and wipe us not off from the face of the earth. (Badenhorst 1923:214)

In haar magteloosheid het Badenhorst (1923:230-231) getwyfel aan die mag van God. In haar staat van twyfel het sy ernstig siek geword en selfs geglo dat sy gaan sterf. Sy het ' $n$ boodskap vir haar man gelaat dat sy na Jesus toe gaan. Sy het nie meer na God verwys as die Sterk Een, of Magtige Vader nie. Sy praat ook nie meer van God nie maar van Jesus - die eerste keer in haar dagboek dat sy na Jesus verwys (Badenhorst 1923:234). In die ellende wat sy gesien en ervaar het in die konsentrasiekamp het sy haar geloof in die tradisionele manlike beelde van God, asook in die menslikheid van die mans wat sy mee te doen gekry het in die konsentrasiekamp, verloor. Die man wat toesig gehou het oor die lyke wat begrawe moes word, het geweier dat die moeders die lyke van hulle babas self na die grafte dra. Badenhorst het dit as onmenslik beskou (Badenhorst 1923:240, 1939:288). Badenhorst (1923:248) beskryf haar ervaring van die konsentrasiekamp soos volg: 'The camp was a terrible sight. In the morning, the dead bodies had to be drawn out from under the fallen tents.' Dit lei daartoe dat sy nie meer tot God kon bid nie (Badenhorst 1923:277).

In Januarie 1901 toe daar 'n meer menslike kampsuperintendent aangestel is, het haar geloof in die goedgesindheid van haar persoonlike God teruggekeer. Maar hierdie keer was haar verhouding nie meer naïef nie. Sy het antwoorde verwag van God. Na die oorlog het haar persoonlike verhouding met God verander. Omdat God ook God se persoonlike verhouding met haar herstel het, het die woede wat sy teenoor God gevoel het, woede teenoor haarself geword. Sy het haar swaarkry gesien as die gevolge van haar sonde en opstand teen God (Badenhorst 1923:315316). Haar Godskonsep het dus gewissel na gelang van haar persoonlike omstandighede. 
Twee vroue het in die besonder 'n alternatiewe stem laat hoor binne die subkultuur waarin hulle gelewe het, te wete Johanna Brandt (1876-1964) en Marie du Toit (1880-1931).

Johanna Van Wermelo is gebore in 1876. Na die SuidAfrikaanse oorlog in 1902, het Johanna vertrek na Nederland. Daar is sy getroud met ds. L.E. Brandt. Hulle het in 1904 teruggekeer na Suid-Afrika. Met haar terugkeer na SuidAfrika skryf sy twee boeke, Het concentratie-kamp van Iréne (1905) en The petticoat commando (1912). In 1916 die jaar waarin sy 40 jaar oud word, sterf haar ma. Sy en haar ma het ' $n$ baie hegte verhouding gehad. Sy het geglo dat sy goddelike openbarings langs die sterfbed van haar ma ontvang het (kyk Landman 1994:95). Gebaseer op hierdie visioene skryf sy haar boek, The Millennium (1918a). In hierdie boek word gelykheid tussen die geslagte en harmonie tussen partye wat oorlog voer, as positiewe alternatiewe aangebied vir die mensdom wat hulle moet regmaak vir die wederkoms van die Here (Brandt 1918a:103-111).

Gedurende hierdie tyd was Brandt se man 'n predikant in die Nederduitsch Hervormde Kerk van Afrika in Johannesburg. Omdat sy 'n vrou was, het haar kerk nie veel aandag gegee aan haar 'ketterse' geskrifte nie. Hulle het haar man wel gevra om hom te distansieer van haar standpunte. Hy het dit gedoen. Ds. Brandt was in hierdie tyd die voorsitter van die Algemene Kerkvergadering van die NHKA (sinode). In 1927 het Johanna Brandt Suid-Afrika verlaat en na Europa en Amerika gereis. Sy het in 1925 'n druiwekuur vir kanker ontwikkel. Sy het erkenning daarvoor ontvang in die vorm van 'n eredoktorsgraad van die American School of Neuropathy (kyk Botes 1989:469). In 1929 keer sy terug na Suid-Afrika. Onder die invloed van die Engelse feminis, dr Anna Kingsford (1846-1888), skryf Brandt haar boek, The paraclete, or coming world mother (1936). In hierdie boek stel Brandt dat wanneer God na die aarde kom, met die wederkoms, God in die vorm van 'n vrou sal kom (Brandt 1936:29). Brandt (1918a:111) lewer ook kritiek op die rassesituasie in SuidAfrika en die dominante manlike kultuur. Hoewel Brandt se boodskap anders was as die van haar voormoeders, hoor 'n mens steeds by haar die piëteit van die voormoeders wanneer sy mense se sonde sien as die oorsaak van rampe (Brandt 1936:70-71). Brandt het baie waarde geheg aan vroue se vermoë om godsdienstige waarhede te verstaan. Sy het ingesien dat die mans onwillig is om die boodskap van gelykheid tussen geslagte te hoor en het gemeen dat vroue hierdie boodskap gretig sou aangryp (Brandt 1936:51). Die vroue van haar tyd het dit egter nie gedoen nie. Hulle was nie gereed om die vroulike aspek van God en die waarde van hulle eie godsdienstige verstaan te aanvaar nie (vgl. Landman 1994:107).

Afrikaanse vroue aan die begin van die twintigste eeu is nie beïnvloed deur die geskrifte van Nederlandse vroue of feministe nie, maar deur dié van Nederlandse mans wie se gedagtes oorgedra is via die Afrikaanse mans wat die dominante kultuur bepaal het waarin die vroue leef. Die enigste vrou wat gereageer het teen die sinodale besluit dat vroue nie mag stem in die kerk nie, en die advies op grond hiervan aan die staat, om vroue ook op politieke gebied geen stemreg te gee nie, is Marie du Toit (1880-1931). Sy was die suster van Dr J.D. du Toit (Totius). In Du Toit (1921) se boek met die titel Vroue en feministe, of iets oor die vroue vraagstuk, waarsku sy Afrikaanse vroue dat die onderdanige rol wat hulle in hulle subkultuur aanvaar het, onnatuurlik is. Sy beskryf hoe dat vroue in die res van die wêreld probeer om die rolle van hulle subkultuur te verander en daarin geslaag het om deel te word van die dominante kultuur (kyk Landman 1994:17). Marie du Toit het Afrikaanse vroue aangemoedig om die sonde- en skuldbesef voor God waarop hulle soveel klem lê, te laat vaar en die lewe en werk van Jesus Christus ten opsigte van vroue te bestudeer. Sy pleit by vroue om hulle minderwaardige en onwaardige gevoel ten opsigte van mans te laat vaar, asook die dislojaliteit teenoor hulle eie geslag en die agterdog waarmee hulle ander mense en ander nasionaliteite bejeën (Landman (1994:17). In Du Toit (1921:37-39) se kritiek oor die plek van vroue in die huisgesin, word die rolle wat aan vroue toegeken is deur die dominante kultuur, duidelik. Vroue word nie gesien as individue nie, maar net as deel van die huisgesin. Sy beskryf die heersende siening rakende die huwelik en huisgesinne soos volg:

Dit heet God handel met huisgesinne; in die huisgesin is die vrou die mindere; sy is dus nie ' $n$ persoonlikheid of indiwidu nie, of mag as sulks nie handel nie .... As die man nie minder ' $\mathrm{n}$ afsonderlike persoon is omdat hy aan ' $\mathrm{n}$ gesin behoort (sy dit vader of seun), waarom beroof dit ' $n$ vrou dan van persoonlikheid ... en wat is sy dan as sy nie 'n persoon is nie? Miskien is sy maar ' $n$ besitting soos een dominee hier te lande ons herhaalde male in die kake gooi; hy sê, aan die man behoort die vrou, die slaaf, die os en die muil, en dit word dan haar ereposisie genoem! (Du Toit 1921:38-39)

Volgens Du Toit (1921:54), het die egskeidingsyfer verminder in lande waar 'wette aangaande huwelik en sede' verander het en vroue en mans as gelyk gesien word. In die lande waar die wette verander het om dit makliker te maak om te skei, is daar nie om dié rede meer egskeidings nie, maar omdat die verhouding tussen die geslagte nie verbeter het nie. Ten opsigte van die stelling dat vroue die swakker geslag is, haal sy dr Julius Bernstein van die Universiteit Halle soos volg aan:

Na oorweging van die onderwerp, is ek oortuig dat God, nog godsdiens, nog gewoonte, nog wet, en nog minder wetenskap ons geregtig om vol te hou dat daar enige wesentlike verskil is in intellek tussen die manlike en vroulike geslagte. (Du Toit 1921:65)

Du Toit (1921) merk ook op wat alles verlore gaan wanneer vroue se gawes en talente nie benut word in die samelewing nie:

Wie weet watter talentvolle vroue Afrika al kon gehad hê was dit nie vir die verlammende, dodende idee wat hier heers omtrent wat ' $n$ meisie en vrou moet wees nie. (bl. 74)

Hierdie 'dodende idee' geld steeds vandag, veral in die konteks van die dominante tekste oor die huwelik en die rol van vroue daarin vir hulleself verstaan. 
In 'n tyd in die geskiedenis van die Afrikaanse samelewing toe dit ondenkbaar en grotendeels onaanvaarbaar was vir vroue om verdere opleiding te ontvang en te werk, is Du Toit (1921:77) van mening dat dit nie net goed sal wees vir vroue nie, maar ook vir die huwelik. Sy stel dit soos volg:

Is dit nie reeds ' $n$ waarborg vir gelukkiger huwelike nie as 'n meisie, terwyl sy onafhanklik is deur haar werk, kan wag om te trou totdat sy seker is dat sy dit wel wil, en dan alleen dié man te neem wat sy inderdaad lief het? Nie trou vir 'n 'home', vir 'n bestaan of deur nood gedrewe nie, wat meestal lei tot ongeluk, maar omdat sy met tyd en met verstand tot die stap wil gaan! (bl. 77)

Oor die manier waarop vroue deur die kerk behandel word, en hoe die Bybel gebruik word om vroue onderdanig te hou, maak Du Toit (1921) die volgende opmerking:

Maar die hele Bybel word erg eensydig en soms baie inkonsekwent teen ons aangehaal. Dit is nie opreg of reg nie en vir ons vroue alles behalwe aangenaam of opbouend. Dit is onbetwisbaar dat ons sekse oor't geheel tot hiertoe hulle kerk en godsdiens trou was, veelal meer godsdienstig en trouer kerkgangers as die mans; al het die mans o.i. meer rede om gelowig te wees as vrouens. Meer dan die helfte van elke kerk se lede is vrouens, dus waarom nie rekening hou nie met die gevoelens van so baie siele? Dit sal tog te betreur wees as ons gaan vervreemd word van die kerk deur die vrouekwessie. (bl. 92)

In 1920 het die Sinode van die Gereformeerde Kerke beslis dat vroue nie mag stem nie, omdat dit dan vir vroue moontlik sou wees om deel te neem aan die regering van die land (Gereformeerde Kerk 1920:81-82). Hierdie argument word gebaseer op die standpunt van Abraham Kuyper (1914:48) wat 'n onderskeid tref tussen die ondergeskikte posisie van vroue in die publieke lewe teenoor die eervolle posisie van vroue in die privaat lewe van die gesin. Dit stem ook ooreen met Karl Barth (kyk Fiddes 1990:140) wat meen dat vrou en man gelyk is voor God in hulle aardse bestaan, dat hulle ook gelyk is in die sin dat hulle mekaar op 'n gelyke wyse nodig het, maar Barth meen dat man en vrou nie gelyk is in die funksies wat deur God aan hulle toegeken is nie. Dit is die funksie van die vrou om ondergeskik en onderdanig te wees aan haar man. Dit is die funksie van die man om leier, inspireerder en inisieerder te wees in hulle gesamentlike lewe. Die vrou moet haar man se inisiatief volg.

Die hiërargiese ordening van man en vrou in die familie en in die samelewing gaan volgens Barth nie oor ' $n$ intrinsieke superioriteit van mans en minderwaardigheid van vroue nie. Tog moet mans en vroue hulle plek en rolle binne God se ordening aanvaar as gehoorsaamheid aan die Goddelike wil (kyk Barth [1939] 1957:169-171). Du Toit (1921) verwerp hierdie onderskeid wat gemaak word en lewer as volg kritiek:

Punt 1 lê nadruk daarop dat ons maar as die hulp bedoeld is, en dus in ' $n$ mindere posisie geplaas is; dit sluit dan (konsuis) nie minderwaardigheid van persoon in nie. Maar iemand wat altyd in 'n mindere posiesie moet bly, sonder 'n vooruitsig, is of word minderwaard; ... oor die mindere posiesie wat 'voortvloei uit andersoortigheid'. Met andere skrywers hou ons vol dat 'n mens 'n ondergeskikte posiesie te gee om hy of sy verskillend is van andere, die grofste onreg is. (bl. 139)
Ongelukkig is die werk van du Toit selde gelees. Vroue het die boodskap van die samelewing dat dit vir hulle belangriker behoort te wees om te lewe vir ander as om hulleself toe te wy aan hulle werk en in hulle geleerdheid te bly glo. Vroue wat wel die keuse uitoefen om hulle toe te wy aan hulle werk en geleerdheid, betaal 'n prys. Hulle word daarvan beskuldig dat hulle nie doen wat vroue 'veronderstel is om te doen' nie (kyk Peacock 1993:75).

\section{Bevinding}

Wat die vrou se plek in die kerk betref, het daar gedurende die veertiger- en vyftigerjare ' $n$ teenstrydigheid in manlike kerkleiers se houding teenoor vroue bestaan. Enersyds is die tradisionele rol van vroue gepropageer, terwyl die veranderende rol van vroue aan die ander kant gesteun is. Eersgenoemde groep was eksponente van die patriargale uitgangspunt dat vroue hulle by 'n spesifieke terrein in die kerk moet bepaal. Hierdie standpunt kom uit die patriargale agtergrond van die Afrikanerkultuur wat swaar steun op die Joodse kultuur met die Ou Testament as basis, waar die vrou as eiendom van die man gereken word en as minderwaardig beskou is. Aan die ander kant was daar predikante wat daarop gewys het dat die plek wat die kerk aan vroue toeken, in stryd is met wat die Nuwe Testament voorhou (Geyser 1948:18; vgl. Van Selms 1948:3). Die ambivalensie in die bespreking van die plek van vroue in die kerk was tot 1977 steeds sterk. In die vroeë tagtigerjare het 'n veranderde siening ten opsigte van die rolle van vroue na vore gekom. Dit kan volgens Barnard-Weiss (1999:77-78) moontlik daaraan toe geskryf word dat vroue as diakens, ouderlinge en predikante ' $n$ realiteit geword het.

Hervormde predikantsvroue het die leiding geneem in die NHSV en het hulle stempel op die vereniging afgedruk. Die siening van die predikantsvroue oor hulle rol in die kerk asook oor die rol van vroue in die kerk was soortgelyk. Predikantsvroue het hulle rol in die kerk in 'n groot mate gedefinieer in terme van wat die kerk van vroue verwag het, naamlik volgens die waardes en norme van die patriargale kultuur (Ras 1943:58). Die NHSV het hulle vereenselwig met die voorbeeld uit die $\mathrm{Ou}$ Testament ten opsigte van vroue se plek in die godsdienstige lewe, asook met die tradisionele interpretasie van hulle Afrikanervoorouers (Oosthuizen 1956-1957:12). Aangesien kinders en alles wat met kinderopvoeding gepaard gaan, deel was van ' $n$ vrou se plig, was die godsdiensonderrig van kinders deur vroue aanvaarbaar (Oosthuizen 1940:82).

Die vrou en veral moeders wat tot die arbeidsmark toetree, was nie gewild onder die kerk se manlike of vroulike leiers nie. Dit is eers in die laat tagtigerjare dat vroue na vore getree het in protes teen amptelike kerklike standpunte oor vroue en in artikels wat die lig gesien het wat die patriargale mag bevraagteken (Barnard-Weiss 1999:83-86; kyk Dreyer 1994; Swart-Russel 1989). Telkens deur die loop van die jare het die waarskuwing van die kant van die manlike kerkleiers opgeklink dat vroue nie in regeerposisies in die kerk mag staan nie (kyk Brandt 1949:64-65). Vroue het hierdie 
standpunt in so 'n mate aanvaar dat hulle eie opinie oor die saak ' $n$ presiese eggo daarvan was. Volgens Barnard-Weiss (1999:232) het die eeuelange kondisionering deur die kerk en samelewing, die diepgewortelde onderdanigheid en minderwaardigheid van die Blanke Suid-Afrikaanse vroue veroorsaak, wat dit vandag steeds vir hulle moeilik maak om as volwaardige en gelyke persone in die samelewing en huwelik te funksioneer. Die ervaring van vroue en die steeds veranderende konteks waarin ons lewe, maak hierdie stand van sake onhoudbaar. Dit maak die transformasie van die diskoerse rondom die huwelik en die praktyk van die huwelik in die konteks van gelowige Afrikaanssprekende vroue, noodsaaklik.

\section{Erkenning \\ Mededingende belange}

Die outeurs verklaar dat hulle geen finansiële of persoonlike verbintenis het met enige party wat hulle nadelig kon beïnvloed in die skryf van hierdie artikel.

\section{Outeursbydrae}

A.B. (Universiteit van Pretoria), was verantwoordelik vir die teksbydrae wat gelewer is, Y.D. (Universiteit van Pretoria), was verantwoordelik vir die supervisie daarvan.

\section{Literatuurverwysings}

Ackermann, D.M., 1984, The role of women in the church - certain practical theological perspectives, in W.S. Voster (ed.), Sexism and feminism in theological perspective, pp. 61-83 University of South Africa, Pretoria. PMid:6480312

Badenhorst, A.M., 1923, Tant' Alie of Transvaal: Her diary 1880-1902, transl. E. Hobhouse, Allen \& Unwin, London.

Badenhorst, A.M., 1939, Tant Alie van Transvaal: Die dagboek van Alie Badenhorst, saamgestel deur MER, Nasionale Pers, Kaapstad.

Barnard-Weiss, M., 1999, 'Die vrou in die Nederduitch Hervormde Kerk van Afrika: Haar beeld en kerklike rol, 1940-1983', DPhil proefskrif, Fakulteit Lettere en Wysbegeerte, Universiteit van Pretoria.

Barth, K., [1939] 1957, Christ and Adam: Man and humanity in Romans 5, transl. T.A. Smail, Macmillan, New York.

Bird, J., 1888, The annals of Natal: 1495 to 1845, vol. 2, P. Davis \& Sons, Pietermaritzburg.

Botes, H.J., 1989, 'Ds. L.E. Brandt (1876-1939) as kerklike leier en bouer', DTh proefskrif, Departement Kerkgeskiedenis, Universiteit van Pretoria.

Brandt, J., 1918a, Millennium, Argus Printing, Johannesburg.

Brandt, J., 1918b, Millennium, Nationale Pers, Bloemfontein.

Brandt, J., 1936, The paraclete or coming world mother, The author.

Brandt, L.E., 1949, 'Enige gedachten over de Evangeliebediening', Almanak van die Nederduitsch Hervormde Kerk van Afrika 45, 64-65.

Brink, E., 1990, 'Man-made women: Gender, class and the ideology of the volksmoeder', in C. Walker (ed.), Women and gender in Southern Africa to 1945 pp. 273-292, David Philip Publishers, Claremont.

Cloete, E., 1992, 'Afrikaner identity: Culture, tradition and gender', Agenda 13, 42-56. http://dx.doi.org/10.2307/4065612

Dreyer, T.F.J., 2008, 'Die kerk, die huwelik en seks - 'n morele krisis?', HTS Teologiese Studies/Theological Studies 64(1), 483- 496. http://dx.doi.org/10.4102/hts. v64i1.9

Dreyer, Y., 1994, 'Seksisme in die kerk - geskiedenis of werklikheid?', Praktiese Teologie in Suid-Afrika 9(1), 55-71.

Du Toit, M., 1921, Vroue en feministe, of iets oor die vrouevraagstuk, Nasionale Pers, Bloemfontein.

Engelbrecht, G., 1981, 'Brief', Die Hervormer 72(11), 14.

Fiddes, P.S., 1990, 'The status of women in the thought of Karl Barth', in J.M. Soskice (ed.), After Eve, pp. 138-155, Collins, London.

Gereformeerde Kerk in Suid-Afrika, 1920, Handelinge van die Sinode, Naspers, Bloemfontein

Geyser, A.S., 1948, 'Paulus en die emansipasie van die vrou', NHSV Jaarboek 1948 $12-21$.
Jonker, M., 1850a, 'Brieven van Mejufv. De Wed. Jonker', De Gereformeerde Kerkbode, Zaterdag, April 6, 1850 (33) p. 121, Die Kerkbode Argief, Kaapstad.

Jonker, M., 1850b, 'Brieven van Mejufv. De Wed. Jonker', De Gerefromeerde Kerkbode, Zaterdag, Junij 29, 1850 (39) p. 148, Die Kerkbode Argief, Kaapstad.

Jonker, M., 1850c, ,Brieven van Mejufv. De Wed. Jonker', De Gereferomeerde Kerkbode, Zaterdag, Mei 4, 1850 (35) p. 208, Die Kerkbode Argief, Kaapstad.

Jonker, M., 1851a, 'Brieven van Mejufv. De Wed. Jonker (no 22)', De Gereformeerde Kerkbode, Zaterdag, Mei 31, 1851 (11) p. 170, Die Kerkbode Argief, Kaapstad.

Jonker, M., 1851b, 'Brieven van Mejufv. De Wed. Jonker (no 23)', De Gereformeerde Kerkbode, Zaterdag, Junij 14, 1851 (12) p. 184, Die Kerkbode Argief, Kaapstad.

Kuyper, A., 1914, De eerepostie der vrouw, Kok, Kampen.

Landman, C., 1994, The piety of Afrikaans women: Diaries of guilt, University of South Africa, Pretoria.

Mulder, E.S., 1949, ,Pligte van die vrou', NHSV Jaarboek 1949, 11.

Nederduitsch Hervormde Kerk van Afrika (NHKA), 1957, Besluite van die H.E. Algemene Kerkvergadering, 07 Maart 1957 e.v.d. te Pretoria. (K1/1 vol 1/1/12D)

Nederduitsch Hervormde Kerk van Afrika (NHKA), 1970, Notule van die ses-envyftigste Algemene Kerkvergadering van die Nederduitsch Hervormde Kerk van Afrika gehou in die Dirk van der Hoff gebou Pretoria, 27 April tot 5 Mei 1970. (K1/1vol 1/1/19)

Nederduitsch Hervormde Kerk van Afrika (NHKA), 1983, Notule van die sestigste Algemene Kerkvergadering van die Nederduitsch Hervormde Kerk van Afrika te Pretoria, 3 Mei tot 10 Mei 1983, (K1/1 vol 1/1/23)

Newton, J., 1840, The works of the Rev John Newton, to which are prefixed, memoirs of is life by Rev R Cecil, Thomas Nelson, Edinburgh.

Nederduitsch Hervormde Sustersvereniging (NHSV) Jaarboek 1967-1968, Kerklike argief van die Nederduitsch Hervormde Kerk van Afrika, besigtig, geen datum, by http://www.nhka.org/index.php/so-werk-ons-11/kerklike-argief.html

Oosthuizen, M.R., 1940, 'Hoe kan die vrou haar plig na kom in die kerklike lewe', in Almanak van die Nederduitsch Hervormde Kerk van Afrika, 1940, 82.

Oosthuizen, M.R., 1956-1957, 'Openingsrede', NHSV Jaarboek 1956-1957, 12.

Pauw, S., 1958-1959, 'Die verbrokkeling van die huisgesin' NHSV Jaarboek 19581959, 37-41.

Pattison, S., 1993, A critique of pastoral care, 2nd edn., SCM Press, London.

Pattison, S., 1994, 'A vision of pastoral theology', Contact Pastoral Monograph 4, 1-32.

Peacock, A., 1993, 'Take my intellect, and use', in E.L. Graham \& M. Halsey (eds.), Life cycles: Women and pastoral care, pp. 71-79, SPCK, Londen.

Philip, J., 1824, Memoir of Mrs Matilda Smit, late of Cape Town, Cape of Good Hope, Westley, London.

Pont, A.D., 1945, Beginsels van huweliksreg', NHSV Jaarboek 1945, 11-14

Pont, A.D., 1981, Die histories agtergronde van ons kerklike reg, HAUM, Pretoria. PMCid:PMC1537413

Postma, W., 1918, Die boervrouw: Moeder van haar volk, Nasionale Pers, Bloemfontein.

Raath, A.W.G., 2003, 'Eensaam in die Voortrekkergemeenskap: Askese en geloofsbelewing in die teologie van die Voortrekkervrou Susanna Smit (17991863)', HTS Teologiese Studies/Theological Studies 59(1), 121-150. http://dx.doi. org/10.4102/hts.v59i1.645

Raath, J.M., 1959-60, 'Die toetrede van die vrou tot die arbeidsmark', NHSV Jaarboek 1959-1960 40-51.

Raath, J.M., 1961-1962, 'Groete van die S.A.V.F.', NHSV Jaarboek 1961-1962, 20.

Ras, M.J.A., 1943, 'Die invloed van ons NHSV', NHSV Jaarboek 1943, 58-62.

Roodt-Coetzee, K., 1961, 'Susanna Smit, skryfster van die Trek', Hertzog-Annale van die Suid-Afrikaanse Akademie vir Wetenskap en Kuns, Jaarboek VIII, Desember 29-44.

Smijtegelt, B., 1856, Het gekrookte riet, of honderd vyf en veertig predikatien over Matt xii:20,21, Nijkerk, Malg.

Smit, S., 1839-1863, 'Ongepubliseerde Dagboeke', Argiefbewaarplek Voortrekkermuseum, Pietermarizburg.

Smit, S., 1843-1863, 'Tikskriftranskripsie van Dagboeke nos 8, 18, 20, 24, 37, 42, 43', Natalse Argiefbewaarplek, Pietermarizburg.

Steenkamp, A.E., 1939, Die dagboek van Anna Steenkamp en fragmentjies oor die Groot-trek (1797-1891), Natalse Pers, Pietermaritzburg.

Stockenström, E., 1921, Die vrou in die geskiedenis van die Hollandse-Afrikaanse volk, s.n., s.l.

Swart-Russel, P., 1989, 'Towards our liberation: a new vision of church and ministry', Journal of Theology for Southern Africa 66, 34-47.

Van Lier, C.A., 1804, Dagboek, gemeenzame brieven en eenzame overdenkingen, J.J. Kicherer (red.), Yzerworst, Utrecht.

Van Selms, A., 1948, "n Woord vooraf', NHSV Jaarboek 1948, 3.

Van Selms, A., 1967, Genesis, deel 1, Callenbach, Nijkerk.

Van Zyl, W.A., 1989, 'n Vergelyking tussen A. Murray en G. Guiterrez se heilsbeskouing', MTh verhandeling, Fakulteit Teologie, Universiteit van Suid-Afrika, Pretoria. PMCid:PMC1203791

Venter, H., 1852, De ondervindelijke van de zalige vrouw Hester Venter, Van de Sandt, De Villiers en Tier, Kaapstad.

Walker, C. (ed.), 1990, Women and gender in Southern Africa to 1945, David Philip Publishers, Claremont. 